\title{
Severe Neonatal Encephalopathy Due to MECP2 Mutations
}

National Cancer Institute

\section{Source}

National Cancer Institute. Severe Neonatal Encephalopathy Due to MECP2 Mutations. NCl Thesaurus. Code C132293.

An X-linked recessive condition caused by mutation(s) in the MECP2 gene, encoding methyl-CpG-binding protein 2. It is characterized by severe neonatal encephalopathy. 